\title{
The Characteristics of Participation of the School Community in a Shared Management Model
}

\author{
Renato de Oliveira Brito ${ }^{1}$ \\ Luiz Síveres ${ }^{2}$
}

\begin{abstract}
The aim of the present study of a qualitative and exploratory character is to analyze what the characteristics of the school community in a shared management model are in a school of the public school network of the Distrito Federal, Brazil, which was honored with the National Award of Reference in School Management (Prêmio Nacional de Referência em Gestão Escolar) and is situated in a financial needy location. Therefore, a bibliographical review and an on-site study was used for the purpose of clarifying the informative objectives upon which successful shared management would be characterized, emphasizing the main points to be pursued and the actions that would be most suitable for this characterization. In this study, the actions and, principally, the degree of participation of the stakeholders (students, teachers, technical-administrative personnel, support staff, parents and community) were observed. The purpose was thus to revise the concepts presented or reaffirm them so as to concretize the models adopted and standards to be followed so that shared management achieves success and becomes a reality in all schools in Brazil.
\end{abstract}

Keywords: shared management. Participation. School-community relationship.

\section{Introduction}

Promoting the evolution of the classic administrative model for the concept of management has become a challenge to overcome for which the school was not prepared. Scientific advancement itself came to require profound changes in the context of organizations, affecting the arrangement of these new models in the administrative field, especially directed to the field of education. In addition to science, industrial advancement, with its new forms of organization and methods, also underwent profound modifications, directly affecting the expectations of the student in regard to the proposals offered by the school since this school space supposedly holds responsibility for job preparation.

Society, more specifically the class to which parents of the students belong, has come to require more efficient and effective action from the school in regard to their child's performance and, thus, the possibilities for involvement in the actions of the school have

${ }^{1}$ Visiting Researcher at the Centre For Social Science Research, University of Cape Town - South Africa (2005), Consultant / Evaluator projects of the Ministry of Education - MEC and the UNDP - United Nations (2008-2011) and Student/Researcher of the Doctoral Program in Education at the Catholic University of Brasilia. Nowadays he is Head of Environmental Sustainability on the Brazilian Government.

2 Post Doctoral Degree in Education on Pontifical Catholic University of São Paulo (PUC-SP) and PHD in Sustainable Development (University of Brasilia), Consultant in Education Field and. Nowadays he is a 
expanded considerably. If, on the one hand, this closer contact has been appreciated by educational professionals, on the other hand, a more skeptical glance has been cast on the closeness of parents since their presence in the school may imply evaluation of its strategies and intensification of the level of demands in regard to results. Thus, a certain unease and feeling of discomfort has arisen on the part of teaching professionals and of the managers themselves from perceiving this closeness as a threat to school autonomy. Nevertheless, in the face of the current state of education in Brazil and flagrant indexes registered by most schools in institutional evaluations, what is observed is that both parties, community and school, have not understood the relationship of dependence between them and the need for this closeness as an element for transformation to move away from the educational chaos which has taken hold. Currently, it is the silence of the community that causes unease and discomfort to the school since the managers have perceived their powerlessness in the face of the magnitude of the challenge to which the school is exposed. In addition, the requirement for democratization of school processes intensifies the need for the manager to rush to seek community support, in this case the community made up of parents of students.

The proposed study sought to make a contribution to academic research in regard to the theme of school management in the perspective of application of the Shared Management project in the Distrito Federal, according to Law no. 4.036 of October 25, 2007. For that reason, we also sought to investigate if the school that constitutes the object of study passed through these three phases, which may be supposed to have occurred, in the intention of implementing and consolidating its successful participative management model. This finding was confirmed and it indicated that the school migrated from a classic style of administration to a school management model guided by innovation, as one of the benefits derived from participation of the school community in its pedagogical-administrative processes. Thus, the purpose of this study was to draw up the characteristics of the participation of the school community in a school that adopts the shared management model.

\section{Bibliographical Review}

\subsection{Shared Management}

In a general perspective, management may be understood as the administrative practice that defines and directs the use of financial, material, information, technological, human and partnership resources, as well as the policies and the alliances for achieving goals (COSTA, 2007). Management is thus physical force and human intelligence, both applied to work. The elements of participation and of human interactions are intrinsic to management, as may be verified in the concept elaborated by Lück (2009, p. 21), according to which management may be understood as "a process for mobilization of the competence and energy of collectively organized people so that through their active and competent participation, they promote, as fully as possible, achievement of the goals of their work unit, in this case, educational goals".

For Campos (2010), school consists of a space of dialogues among all those that affect or are affected by the educational process, generating, as a result of this dialogue, a school pedagogical-administrative project that results from the exchange of experiences for the livelihood of all the stakeholders. This action is what contributes so that they commit themselves with a focus on positive results. Thus, in order that participation occurs, the 
school must be managed so as to allow interaction between agents inside and outside the institution.

Nevertheless, it is known that most schools are still managed according to the principles of classic administration, as stated by Glautter (1992 apud SANTOS, 2008). For the author, the new world order, regulated by technology and knowledge, comes to require a new posture from the school, which makes school management become a means of innovation and change. Thus, the process of change in the school management model passes through three phases: (Phase 1) introducing new ideas and practices looking toward institutional approval; (Phase 2) implementing the new practices and ideas, which are established at the time of the action and of the operationalization of that which was planned; (Phase 3) institutionalization of the standards and routines that were placed in the school environment, a phase in which the new practices and ideas that were implemented are finally incorporated in the organizational culture and they become an integral part of the school work. It is also observed that, according to Motta:

In the sphere of the school, participation constitutes a theme of students, teachers, administrators, supervisors, advisors and employees. Educational administrators have the particularly significant challenge of discovering and designing organizational formats, suitable to specific contexts, that ensure participative education directed to building up a truly egalitarian society, not only in economic terms but in terms of power distribution (MOTTA, 2003, p. 5).

The main deliberative institutions in the schools are: the Student Council (Grêmio Estudantil), the School Council (Colegiado Escolar or Conselho Escolar) and the Conselho de Classe (Student Evaluation Board). The Student Council consists of students and has the purpose of promoting cultural, artistic, leisure and other events. It may be established as a space for socialization, creation of new knowledge, of creativity, or of development of student projects addressing important themes, such as socioenvironmental responsibility, entrepreneurialism, professional training and other areas.

The Conselho de Classe has the purpose of monitoring and evaluating the pedagogical performance of the students, and, consequently, teaching practice. It is composed of teachers of the diverse subjects, pedagogical coordinators, specialists and students, and it meets periodically. The School Council, on the other hand, is made up of students, teachers, employees, community members, and parents, in short, all representatives of the entire school community. This important body deliberates, among other issues: definition of goals to be reached in accordance with the intentions defined by the school collectively in the Educational Policy Project (Projeto Político-Pedagógico); definition of methodologies and strategies suitable for the proposed goals; indication of criteria for selection of significant, interdisciplinary and contextualized curricular content; definition of themes of interest of the inside and outside community in relation to the school; and selection of significant thematic areas; and system of assessment and student remedial work.

The introduction of a participative management model in a school consists of a complex process that presupposes the existence of a real sphere of autonomy of the school and recognition of the different responsibilities and attributions of the organizational members (BARROSO, 2008). As a participative management model, it must be seen as a permanent process of establishment of a dynamic balance among the educational directors, the professional responsibilities of the teachers as teaching specialists and of 
other non-teaching workers, students rights as authors of their own growth, and the responsibility of parents in the education of their children.

It is known that the participation of the diverse members of the school community in the school deliberative bodies ends up constituting an explicit strategy of administration with a focus on results (BERALDO e PELOZO, 2007). This is consistent with the thought of Santos (2004), according to which school management is only democratic if it is carried out in line with the principles of participation and autonomy.

\subsection{The Importance Of Community In The School Environment}

Participation in the school context may occur in diverse manners, and Lück (2009) cites the following: participation as presence, participation as verbal expression and discussion, participation as political representation, participation as decision-making and participation as engagement. Each one of these forms of participation contains a different and stepwise intensity in its level of interaction. To be successful, a participative school management model must promote means for the community to be motivated in a sequential and growing manner to be present in the school; to participate in discussions and debates regarding the viability of implementing new ideas and projects in the school; to deliberate in the decision-making process regarding which ideas and projects debated will really be implemented in the school; and to get engaged in carrying out the actions necessary for implementation of the chosen projects.

Among the diverse stakeholders that make up the school community, as verified in Figure 1, the local community of which the school is part is that which remains most distant from school management, and, in traditional models of school management, the community tends to remain totally removed from the projects instituted in the school. Thus, it is considered that only a well-planned and well-implemented model of

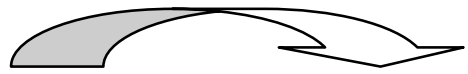

Figure 1-School Community - the stakeholders that affect and are affected by the educational process.
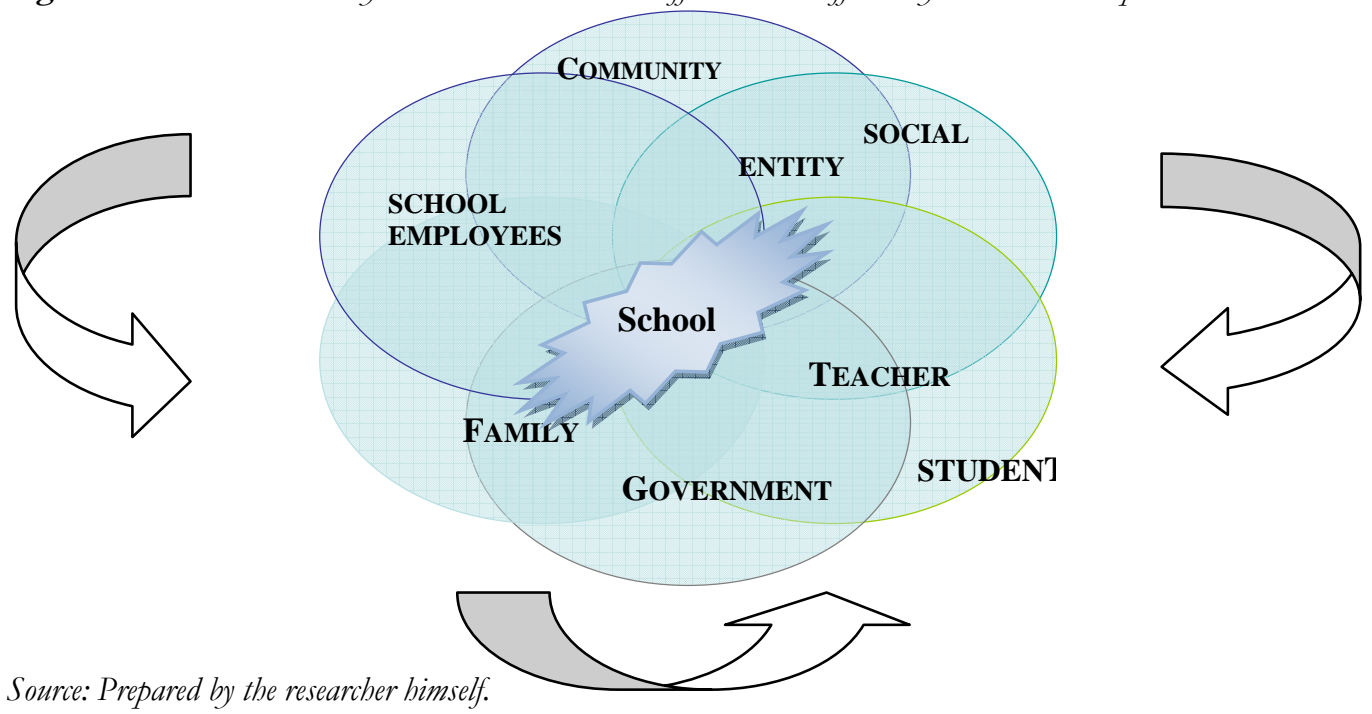

Source: Prepared by the researcher himself. 
participative management constitutes an element capable of bringing about closer contact with the local community of the school.

The school organization has interfaces through which it interacts with the entire medium, which is composed of diverse stakeholders. By means of the relationship with these agents arises the School-Government-Community synergy, which results in important public-private partnerships. Within this perspective, community and private companies join to positively affect the educational decision-making process. However, we emphasize that it is important to have a coherent pedagogical project that does not allow public-private partnerships to interfere in the purposes of education.

It is considered that the environment favorable to development of a participative management model may only be considered complete if there is participation of the local community of which the school is part for, after all, "school management involves creation of a participative environment” (LÜCK, FREITAS, GIRLING, KEITH, 2010, p. 19). For Murillo et al. (2007), a collaborative model in school organization within an administrative-pedagogical policy which deals with the student, knowledge, the student body and the community as its main elements, is a basic requirement for qualification of the school. According to the presentation of the author, school qualification is composed of training the school to meet the new requirements of society and, consequently, of the students, at a time governed by speed and importance of access to technology and to knowledge.

Within a participative educational management model, the school is planned to be transformed into a permanent communitarian center because the integration among school-family-community is broadly applied. Such a shared management model leads parents, teachers and students to show satisfaction in relation to the service offered by the school (SANTOS, 2008).

As may be observed in Figure 2, involvement of the community in the school is one of the most important factors of the shared management model:

Figure 2. A reference diagram for improvement of school effectiveness.

Source: Murillo et al. (2007, page30)

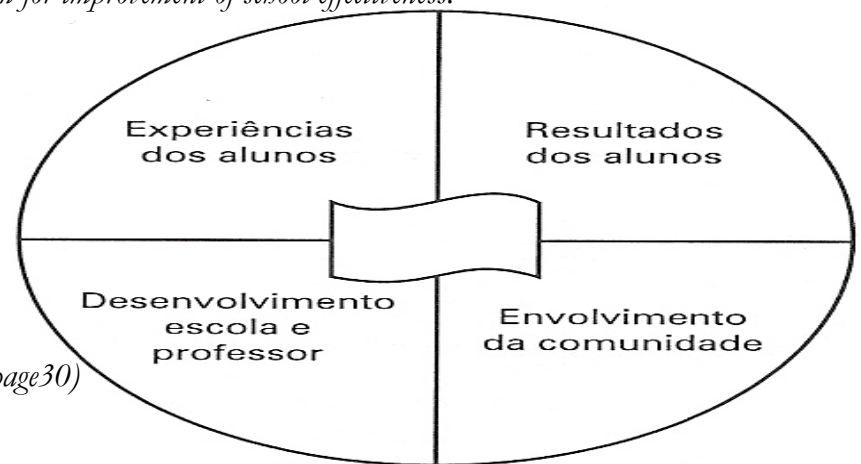

(Student experience, student results, community involvement, school and teacher development)

This involvement in the sphere of shared management has processes available which constitute motivating elements for collaboration between the school and families, with shared goals and vision, directed to a process where participation of the school community in the construction and implementation of the educational policy project becomes a key factor for success (MURILLO et al 2007). 


\section{Methodology}

In regard to the approach taken, in the case of this study, the presuppositions of the qualitative methodology were adopted. According to Weller e Pfaff (2010, p. 34), the use of qualitative research methods contributes in a significant way to advancement in the processes of construction of knowledge in the area of Education, allowing "better understanding of school processes, of learning, of relations of institutional and cultural processes, of socialization and sociability, of daily school life in its multiple implications". Furthermore, in regard to the methodological approach, a bibliographical survey was developed, followed by the method of textual, thematic and interpretive analysis and documental research as a means of examining the publications, the process through which analysis of productions that compose files of public bodies or private institutions that have not yet received analytical treatment is performed (PEDRON, 1999). The investigation furthermore included field research, which occurred through application of semi-structured interviews with parents and teachers.

Six teachers were interviewed, all with more than 1 (one) year of work in the same school unit and more than ten years in the Office of Education. This shows that all the teachers interviewed were able to compare the old model to this new project of shared management. Four parents of students were also interviewed, without concern for degree of schooling or the sex of the interviewees, but for the purpose of trying to most fully extract the conception the community has of the shared management model, and if they understand the role of this new school in the formation of the community as a whole.

As a way of maintaining the anonymity of the interviewees and to facilitate reference to their reports, teachers were designated with the letter $\mathrm{D}$, followed by a number from 1 to 6 , and the parents, whether only mothers or the couple, with the letter P, followed by a number from 1 to 4 .

\section{The School Object of Study}

The school which composed the object of study of this research is located in planaltina, df, brazil, and received the national award of reference in school management in 2009 in the distrito federal, considering that the approval rate of its students increased from $71 \%$ to nearly $90 \%$. According to the census of 2010 , the population of this school was 1217 students, 65 teachers and 35 employees of the administrative staff. In principle, the effective participation of the school community is seen as the strategy which brought about this result. It is understood, a priori, that receiving this award resulted from the shared management proposal which involves teachers, employees, students, families and community representatives.

An example of this participation is the "Count on Me" Project (Projeto "Conte Comigo"), in which the residents of Planaltina make registration and report what they can contribute for improvement of the school. Contributors range from store owners that make materials and labor available to people that dedicate some hours up to volunteer work. The school prepares a file of volunteers and seeks them out when it needs contribution for some project. 
Within the participative management model used in the school, the principal, teachers, employees, students, families and community representatives join forces around a single goal: quality teaching. The pedagogical proposal of the school includes 27 projects developed with the collaboration of the community, of local institutions and partnerships with other cities of the DF. These projects are directed at themes such as the environment, drug prevention, peace and citizenship, dietary education, computers, literature, sciences, talents in local culture, music, sports, correction of age-grade difference and martial arts. On weekends, the school undertakes events for meet community needs.

\subsection{The educational policy project of the school (PPP)}

The educational policy project (projeto político pedagógico - PPP) of the school is a plan that presents all the strategies and objectives that will be followed by it so as to achieve, in the best way possible, its mission of educating and creating informed citizens. Thus, all the pedagogical directives of the school are defined in it. In a shared management model, the manager directs the application of this document, which is formulated and implemented with the aid of the entire school community.

The school gives priority to meeting the needs that the community presents; an example of this is Youth and Adult Education (Educação de Jovens e Adultos - EJA $1^{\circ}$ e $2^{\circ}$ seguimentos), which was implemented in the school due to community request. In addition, the school has a listing of multidisciplinary projects, all undertaken with the participation and encouragement of the community. Some were given awards of recognition, both for the school and for individual students. The PPP itself highlights the publication of a book, written by students of the 1st grade whose main theme is the environment, specifically conservation of a park which is located in the proximity of the community. The book, published in 2004 and entitled "Sucupira Park is Ours", had a printing of 800 copies.

The introductory part of the PPP ends with presentation of the theme that will be dealt with during the year and the subthemes divided up in two month periods, making clear from the beginning of the school year what will be worked on and the way this work should be developed over the following months. The PPP also presents the overall goal, the specific objectives, the guiding principles (epistemological, didactic-pedagogical, ethical and aesthetic) and the administrative organization of the school in reference to 2010. In this part of the PPP, the failure rate, dropout rate, grade repetition rate and approval rate per group (morning, afternoon, evening) are presented.

\section{Data Presentation And Analysis}

The relationship between school and community within a democratic pedagogical plan is a vast and rich theme, both in knowledge of the evolution of education and in the importance of the role of the school for forming the character of its students. Thus, for the purpose of attempting to schematize what the main factors were for successful shared management, in this topic, the most relevant aspects were dealt with, indicated by those who are closely connected with the model of democratic management, in other words, teachers and parents of students.

Upon analyzing the content of the interviews (the interviewees were free to express their opinions in a natural way), it may be observed that the conception of shared 
management or democratic management goes far beyond the designation of this model; in other words, even without having used the designations "shared management" or "democratic management", the essence of this model was present in the discourse of the interviewees when they referred to the school as "our school", to the collective body as teamwork and to the pride of feeling part of the whole.

\subsection{Characteristics Of Participation Of The School Community In A School That Adopts The Shared Management Model}

Communication is palpable in various sections of the interviews when the parents of students mention the summoning of the school not only for knowing what is happening with their children, but especially when they are offered the possibility of seeing and learning together with their family members.

Such communicability is also applied to the teachers that, just like the community, are called to participate not just in the educational projects during the school week, but also in the extracurricular activities:

We, as teachers, always end up participating in everything that happens in the school, everything that is involved with our student, everything the school itself organizes, within the area of the school itself and outside of it, like extracurricular activities; at all these times we are participating. When some decision has to be made regarding the future of the student, in relation to kicking off some project within the school, or that the school will participate in in another place, that is not at the school strictly speaking. So the teacher is involved all the time. (D1)

The community showed it recognized that participation must be effective and constant, not only in relation to grades and parent-teacher meetings, but also in extracurricular activities carried out by the students outside their habitual study schedule, including weekends, "it is parent meetings, pedagogical meetings, it is family day, social gatherings... We are present at everything" (P2).

Such an interest is also perceived by the teachers that seek, in the light of their privileged knowledge, that which affects the students, improving and suiting the school projects to the needs of the community. The choice of projects is always directed to the collective interest. The teachers propose themes and activities according to the reality of the students and to that which attracts them:

Because I keep thinking that in their reality, since it's a community that doesn't offer a lot on the weekend, they don't have much leisure activity. And by the experience that I have, because I've already had a lot of students, what I see in the school when I finish class, and I see a lot of young people between the ages of 18 to 22, idle, without doing anything. So they don't have anything to do, and I know a lot of them already got involved with drugs, alcohol. The school has a very good laboratory, it has data show, the classrooms have television, they have DVD, I myself bought various DVDs about these themes I work with. There isn't the material itself, but in this context, there's everything. And the school opens on the weekends, and the students come to the court to play, on Saturday. This is a really good seed we're planting because there are a lot of idle people in the community, and since it is a low income community, well it's really easy for them to get mixed up with drugs. (D5). 
The parent-teacher meetings are the high point of parent participation as well as handing out report cards, and when there are behavior or learning problems of the students. In this last situation, in a specific manner, parents are duly made aware of the conduct and called to talk with the teachers and advisors. But there are also the semester and bimonthly consultations, in addition to the coordination meetings, where the teachers discuss the projects and activities that will be worked on and the way they will be applied and disclosed:

Here we participate more in collective moments, which is at the time of coordination. This is also the time when we discuss school things, what the proposals are, everything within the morning time and of coordination (D6).

Thus, direct communication between the school and the community proved to be quite a strong characteristic of the participation of the community in school life.

From the following extract, it is possible to verify, through the words of a teacher, that the process of dialogue among teachers, school direction and parents in the school is quite open, and this facilitates achievement of positive results:

There is coordination, there is supervision, school direction that are always helping you to work, so that motivates you - to look for new things and bring them to the school. To give ideas, because you know you're going to be heard [...]. I tell the parents from the beginning of the year, "Look, I am this type of teacher, I have this type of conduct, I want to develop this type of work" and the parents, most of them, until now, have agreed, "That's great, teacher". So the parents, they leave this endorsement, this freedom for you to take care of their child because we in the school provide a lot of care. So if you, for example, ask for something with the participation of the parents, they come without any problem. So this really motivates collaboration of the school and of the parents too. (D3)

Thus, it was verified in the school under study that the channels of communication between the school team, the parents, the students and their family members are key factors for success and constitute an important strategy that helps to establish a participative school practice directed to shared management.

\section{Final Considerations}

The network of interaction between the members of the school community will bring positive results to the school only if there is an unobstructed channel of communication between them. Therefore, a very important component in shared school management is communication, and school management must be a connecting bridge between all the subjects that make up the school, finding mechanisms that facilitate the spread of information in respect to progress of school projects, and, at the same time, making all the members of the school community talk among themselves. A good communication process among the se members helps to define consensus items and avoid conflicts, favoring the prevalence of transparency and democracy in the participative process.

One of the most striking characteristics of the participation of the school community in the school whose model is shared management was the constant and 
reciprocal communication between the school (directors, assistants, supervisors and teachers) and the community itself.

Thus, the most important characteristics identified by this research as elements which motivate participation of the school community in a school that adopts the model of shared management are: commitment of management in formulating and implementing an educational policy project which favors the participation of the school community, establishment of efficient communication channels among the members of this community; creation of events in the school calendar which provide for the effective action of parents and family members within the school, such as workshops, commemorations, shared team competitions and meetings; respect; and establishment of frank and open dialogue among all.

\section{References}

BARROSO, João (2008). Para o desenvolvimento de uma cultura de participação na escola. In: Cadernos de Organização e Gestão Curricular. Lisboa: Editora Instituto de Inovação Educacional.

BERALDO, Fernando e PELOZO, Rita de Cássia Borguetti (2007). A gestão participativa na escola: tendências e perspectivas. In: Revista Científica Eletrônica de Pedagogia - Ano V, n. 10, jul. Retrieved July 8, 2010 from http://www.editorafaef.com.br.

CAMPOS, Casemiro de Medeiros (2010). Gestão escolar e docência. (Coleção pedagogia e educação). São Paulo: Paulinas.

COSTA, Eliezer Arantes da. Gestão Estratégica: da empresa que temos para a empresa que queremos. 2. Ed., São Paulo: Saraiva (2007).

ESCOLA DE ENSINO FUNDAMENTAL NOSSA SENHORA DE FÁTIMA. Retrieved February 15, 2011 from http://cefnsf.blogspot.com/2009/08/planaltina-150-anos.html.

IDEB. Retrieved November 20, 2011 from http://ideb.inep.gov.br.

INSTITUTO NACIONAL DE ESTUDOS E PESQUISA EDUCACIONAIS ANÍSIO TEIXEIRA. Brasília, 2006. Resultados do IBEB 2005 a 2009. Retrieved June 10, 2010 from www.inep.gov.br.

LÜCK, H. (2009) A gestão participativa na escola. 5. ed. Série: Cadernos de Gestão Petrópolis, RJ: Vozes.

MINISTÉRIO DA EDUCAÇÃO E CULTURA Apresenta textos e dados sobre a educação no país. Retrieved February 10, 2011 from http://www.mct.gov.br.

MOTTA, Fernando C. Prestes (2003, July-December). Administração e participação: reflexões para a educação. In: Educação e Pesquisa, São Paulo, v.29, n.2, p. 369-373.

MURILLO, F. Javier et al (2007). A qualificação da escola: um novo enfoque. - Porto Alegre: Artmed.

PEDRON, Ademar João (1999) Metodologia Científica: auxiliar do estudo, da leitura e da pesquisa. 2. ed. Brasília: Gráfica Redentorista.

SANTOS, Ana Lúcia Felix dos (2004). Gestão democrática da escola: bases epistemológicas, políticas e pedagógicas. Estado e Política Educacional / n.05. Retrieved July 8, 2010 from www.scielo.com.

SASTRE, Marta Gutiérrez (2003). Participación y poder: uma reflexión sobre lãs dificultades Del proyecto participativo em La escuela. In: A gestão da educação na sociedade mundializada: por uma nova cidadania. Ferreira, Naura Syria Sapareto (org.). Rio de Janeiro: DP\&G.

VICENTINI, Almir (2010). Gestão Escolar - dicas corporativas: nossas escolas estão prontas para os desafios do mundo corporativo? - São Paulo: Phorte.

WELLER, Wivian (2010). Metodologias da pesquisa qualitativa em educação: teoria e prática. PFAFF, Nicolle (org.) Petrópolis, RJ: Vozes. 